\title{
Insulin Promotes Survival of Amyloid-Beta Oligomers Neuroblastoma Damaged Cells via Caspase 9 Inhibition and Hsp70 Upregulation
}

\author{
M. Di Carlo, ${ }^{1}$ P. Picone, ${ }^{1,2}$ R. Carrotta, ${ }^{3}$ D. Giacomazza, ${ }^{3}$ and P. L. San Biagio ${ }^{3}$ \\ ${ }^{1}$ Istituto di Biomedicina e Immunologia Molecolare “A. Monroy", Consiglio Nazionale delle Ricerche, Via U. La Malfa, 153, \\ 90146 Palermo, Italy \\ ${ }^{2}$ Dipartimento di Chimica e Tecnologie Farmaceutiche, Università di Palermo, Via Archirafi, 36, 90146 Palermo, Italy \\ ${ }^{3}$ Istituto di Biofisica, Consiglio Nazionale delle Ricerche, Via U. La Malfa, 153, 90146 Palermo, Italy
}

Correspondence should be addressed to M. Di Carlo, di-carlo@ibim.cnr.it

Received 4 December 2009; Revised 24 February 2010; Accepted 24 February 2010

Academic Editor: George Perry

Copyright () 2010 M. Di Carlo et al. This is an open access article distributed under the Creative Commons Attribution License, which permits unrestricted use, distribution, and reproduction in any medium, provided the original work is properly cited.

\begin{abstract}
Alzheimer's disease (AD) and type 2 diabetes are connected in a way that is still not completely understood, but insulin resistance has been implicated as a risk factor for developing AD. Here we show an evidence that insulin is capable of reducing cytotoxicity induced by Amyloid-beta peptides (A-beta) in its oligomeric form in a dose-dependent manner. By TUNEL and biochemical assays we demonstrate that the recovery of the cell viability is obtained by inhibition of intrinsic apoptotic program, triggered by A-beta and involving caspase 9 and 3 activation. A protective role of insulin on mitochondrial damage is also shown by using Mito-red vital dye. Furthermore, A-beta activates the stress inducible Hsp70 protein in LAN5 cells and an overexpression is detectable after the addition of insulin, suggesting that this major induction is the necessary condition to activate a cell survival program. Together, these results may provide opportunities for the design of preventive and therapeutic strategies against AD.
\end{abstract}

\section{Introduction}

Alzheimer's disease $(\mathrm{AD})$ is the most common form of dementia in the elderly. It is characterized by neuronal cell loss and progressive accumulation of neurofibrillary tangles (NFT) in neurons, and amyloid fibers in neuritic (senile) plaques and in the walls of blood vessels [1]. This physiopathological disorder causes a gradual loss of memory and judgment. As the disease progresses, $\mathrm{AD}$ patients experience changes in personality, behavior, and social interactions.

Amyloid beta peptide (A-beta) is the major component of amyloid plaques in the brain of individuals affected by AD. The formation of the plaques is due to an overproduction of A-beta through enzymatic cleavage of the larger amyloid protein precursor (APP). While the monomeric A-beta is not neurotoxic, under specific conditions it is able to misfold from its soluble form into small oligomers and highly ordered fibrillar aggregates. This phenomenon is known as the aggregation of proteins and it is a characteristic feature of several neurodegenerative diseases [2]. Although neuronal degeneration occurs near the amyloid plaques, some studies have suggested that intermediates such as protofibrils or simple oligomers are also involved in $\mathrm{AD}$ pathogenesis and even appear to be the more dangerous species in the onset of the pathology [3].

Genetic researches have demonstrated that only a small fraction (about $5 \%$ ) of all $\mathrm{AD}$ cases is caused by inherited alterations with precocious symptom appearance (before age 65) [4]. The early AD onset is, in most cases, originated by mutations in three genes: APP, PSEN1, and PSEN2. As a result, a large amount of A-beta toxic fragments is produced and deposited as plaques. The great majority of all $\mathrm{AD}$ cases is sporadic in origin, with old age $(>65)$ as the main risk factor.

The "amyloid cascade hypothesis" has tried to explain the origin of the disease. This theory postulates that the deposition of A-beta is the origin of the pathology and that cell loss, dementia, and vascular damage are strictly linked with this deposition. This hypothesis can give an explanation for the $\mathrm{AD}$ early onset but it is not viable for the $\mathrm{AD}$ sporadic form. Indeed, patients affected by $\mathrm{AD}$ late-onset very rarely 
present APP, PSEN1, and PSEN2 gene mutations. Further, the presence of the plaques can also be observed in the elderly without $\mathrm{AD}$ development [5].

Type 2 diabetes is associated to a reduced ability of insulin to stimulate glucose utilization (insulin resistance). It has been recently recognized that $\mathrm{AD}$ is closely linked to the diabetes mellitus in a way that it is still unclear and a deficiency in the glucose metabolism can be considered a risk factor in the sporadic AD onset [6-8]. Further some diabetes drugs appear to slow the cognitive decline associated with $\mathrm{AD}$ [9]. It has been also demonstrated that extracellular injection of insulin is able to protect neurons against A-beta induced cell death [10].

It has been reported [11] that insulin can protect cultured rat neurons against A-beta induced toxicity. Experimental data [12] have demonstrated that A-beta competes for binding of insulin to its receptor. This results in a decrease in autophosphorylation of the insulin receptor. However, it is not understood if this effect was originated through the binding of A-beta to insulin or directly to the insulin receptor. By using mature cultures of hippocampal neurons it was found that A-beta soluble oligomers (also known as ADDLs) caused loss of the activation of insulin receptors (IR) on the neuronal surface, and this event was linked to disruption of insulin signaling [13]. Other studies indicate that insulin, interacting with A-beta, inhibits its fibrillar growth as shown in a cell-free assay and in the cell surface of human brain pericytes [10] reducing the A-beta toxic effect.

Recently, in two different model systems, sea urchin embryo and neuroblastoma cell line, it has been demonstrated that A-beta oligomers are more toxic than larger and highly structured fibrils $[14,15]$. In particular, oligomers and fibrils, involved in the neurodegenerative process are able to induce two different apoptotic pathways [15]. The authors postulate that the large fibrils, remaining on the extracellular space and obstructing the membrane functional channels, can induce an extrinsic programmed cell death pathways through the activation of caspase 8 only. On the contrary, the small oligomers are able to penetrate into the cells. They, damaging the mitochondria, cause a release of the cytochrome $\mathrm{C}$ that, in turn, induces activation of the intrinsic apoptotic pathway by the intervention of the caspase 9 .

The present study is addressed to investigate whether insulin is able to protect cells by A-beta oligomers toxicity, through inhibition of specific apoptotic pathways activation.

\section{Materials and Methods}

2.1. Cell Cultures and Treatments. LAN5 human neuroblastoma cell lines were plated onto 96-well plates at a density of $6 \times 10^{4}$ per well and cultured with RPMI 1640 medium (CELBIO) supplemented with $10 \%$ fetal bovine serum (FBS) (GIBCO) and $1 \%$ antibiotics $(50 \mu / \mathrm{mL}$ penicillin and $50 \mu \mathrm{g} / \mathrm{mL}$ streptomycin) and antimycotics (SIGMA). Cells were maintained in humidified $5 \% \mathrm{CO}_{2}$ atmosphere at $37^{\circ} \mathrm{C}$.

In order to obtain the oligomers, recombinant $A \beta 42$ $(\mathrm{rA} \beta 42)$ was dissolved in $0.01 \mathrm{M}$ Tris $\mathrm{HCl}$ buffer at $\mathrm{pH} 7.2$ [14] and insulin (SIGMA) in HEPES buffer at pH 8.2.
Cells were treated with two different concentrations 25 and $40 \mu \mathrm{M}$ of oligomeric $\mathrm{rA} \beta 42$ [14] for $1 \mathrm{~h}$. After this treatment $\mathrm{rA} \beta 42$ was removed and the cell were incubated without or with insulin at different concentrations (50, $100,200 \mu \mathrm{M})$ in medium serum free at $37^{\circ} \mathrm{C}$ for $20 \mathrm{~h}$. For successive experiments we selected the A-beta oligomer and insulin concentrations at 40 and $100 \mu \mathrm{M}$, respectively. In caspase assays, the incubation time with insulin was $4 \mathrm{~h}$. The treated cultured cells and the controls were morphologically analysed by microscopy inspection using an Axioscop 2 microscope (Zeiss, USA) or used for specific assays. Depending on the experiments we also utilized, as controls, both the untreated cells and the cultured cells with buffers at the concentration utilized to dissolve $\mathrm{rA} \beta 42$ or insulin.

2.2. Determination of Cell Viability. Cell viability was measured by MTS assay (PROMEGA). MTS [3-(4,5dimethylthiazol-2-yl)-5-(3-carboxymethoxyphenyl)-2-(4sulfopheyl)2H-tetrazolium] was utilized according to the manufacturer's instructions. After treatments of the cells, $20 \mu \mathrm{L}$ of the MTS solution were added to each well, and the incubation was prolonged for $4 \mathrm{~h}$ at $37^{\circ} \mathrm{C}, 5 \% \mathrm{CO}_{2}$. The absorbance was read at $490 \mathrm{~nm}$ on the Microplate reader ${ }^{\text {wallac }}$ Victor $^{2} 1420$ MULTILABEL COUNTER (Perkin Elmer). Results were expressed as the percentage of MTS reduction as regard to the controls.

2.3. Apoptosis Assay. TUNEL assay was performed according to the manufacturer instructions (PROMEGA). Briefly, cells untreated or after treatment with $\mathrm{rA} \beta 42$ alone or with insulin were fixed with $4 \%$ paraformaldehyde in PBS for $30 \mathrm{~min}$. Then they were washed with PBS, permeabilized with $0.2 \%$ Triton X-100 in PBS for 5 min, rinsed with PBS and incubated with TUNEL reaction mixture (enzyme, nucleotides) in an humidified atmosphere at $37^{\circ} \mathrm{C}$ for 1 hour. Staining was obtained by using a peroxidase substrate, hydrogen peroxide and the stable chromogen, diaminobenzidine (DAB). After this procedure, samples were rinsed three times with PBS and analysed under Zeiss Axioscop microscope.

2.4. Mitochondrial and Nuclear Staining. One vial of Mito red was dissolved in DMSO according to the manufacturer instructions (SIGMA). Living cells were incubated with $20 \mathrm{nM}$ Mito red for $5 \mathrm{~min}$ and red staining indicates that the mitocondrial is active. For nuclear staining, cells were incubated in the Hoechst $33258(5 \mu \mathrm{g} / \mathrm{mL})$ for 30 min and intense blue staining indicates nuclear fragmentation. Nuclear morphology and mitochondrial activity were analyzed by microscopic inspection using a Leica DHL fluorescent microscope at excitation/emission wavelengths of $350 / 450 \mathrm{~nm}$, respectively.

2.5. Caspase Assays. Caspase- $8,-9$, and -3 activities in cells were measured using commercially available luminescent assays (caspase-Glo 8, caspase-Glo 9 and caspase-Glo 3/7 assay systems, PROMEGA). LAN5 cells were treated with oligomers alone or with insulin. LAN5 cells untreated or 


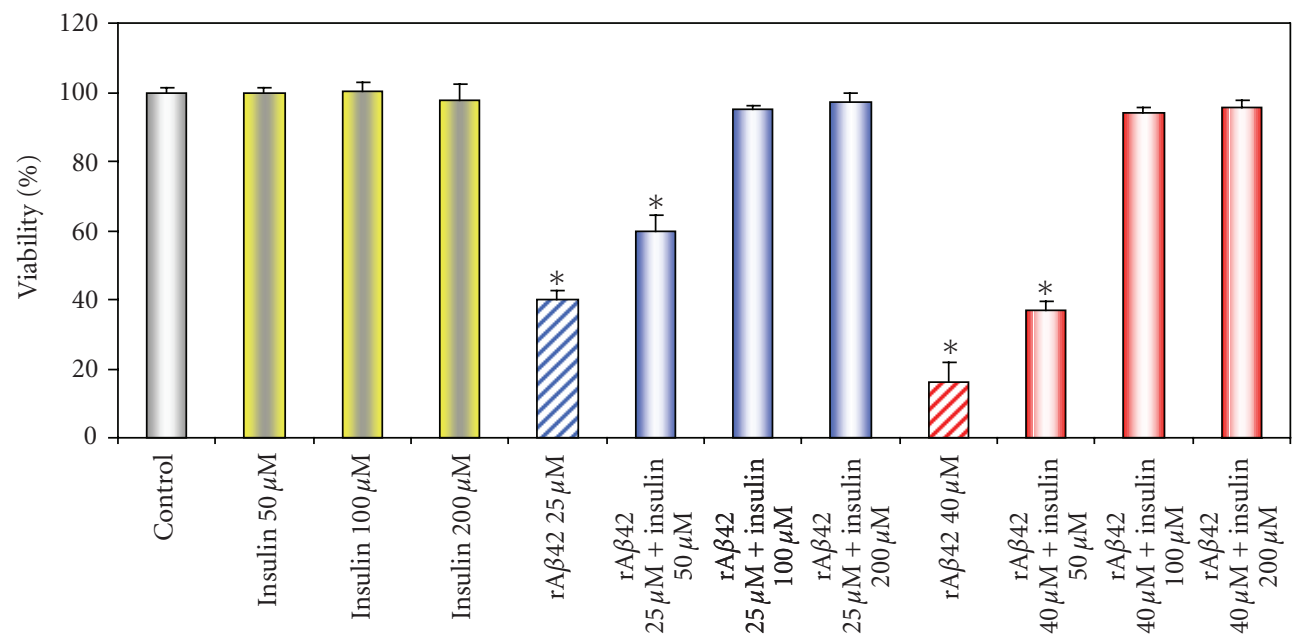

(a)
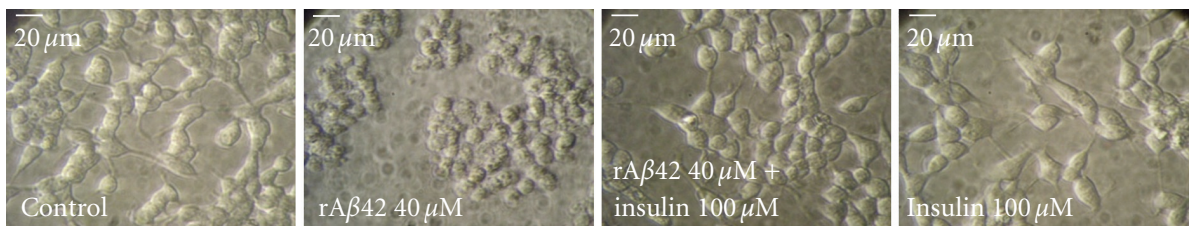

(b)

FIGURE 1: Dose dependence of protective effect of insulin against rA $\beta 42$ oligomers induced cell death. (a) LAN5 neuroblastoma cells were untreated (control) or incubated with insulin 50 or 100 or $200 \mu \mathrm{M}$ of insulin alone or after incubation with 25 or $40 \mu \mathrm{M}$ of rA $\beta 42$. After incubation treated and untreated cells were submitted to viability MTS assay. Cell viability is significantly lower in $\operatorname{rA} \beta 4225 \mu \mathrm{M} * P<.01$, $\mathrm{rA} \beta 4225 \mu \mathrm{M}+$ insulin $50 \mu \mathrm{M} * P<.01$ versus control, whereas it is not significantly lower with $\mathrm{rA} \beta 4225 \mu \mathrm{M}+$ insulin $100 \mu \mathrm{M}$ versus control. Cell viability is significantly lower in $\mathrm{rA} \beta 4240 \mu \mathrm{M}{ }^{*} P<.003, \mathrm{rA} \beta 4240 \mu \mathrm{M}+$ insulin $50 \mu \mathrm{M} * P<.003$, whereas it is not significantly lower with $\mathrm{A} \beta 40 \mu \mathrm{M}+$ insulin $100 \mu \mathrm{M}$ versus control. Percentage of viability is referred to control, the data are the mean \pm SD of three separate experiments. (b) Representative morphological images of LAN5 untreated cells (control), treated with $\mathrm{rA} \beta 4240 \mu \mathrm{M}, \mathrm{rA} \beta 4240 \mu \mathrm{M}$, and insulin $100 \mu \mathrm{M}$, insulin alone $100 \mu \mathrm{M}$. Bar $20 \mu \mathrm{m}$.

treated with insulin alone were used as control. Caspase reagent specific for each kit was added directly to the cells in white 96-well plates and after mixing, they were incubated for 15-30 min before recording luminescence with ${ }^{\text {wallac }}$ Victor $^{2} 1420$ MULTILABEL COUNTER (Perkin Elmer) apparatus. The caspase activator assay was performed using $50 \mu \mathrm{M}$ vinblastine (SIGMA).

2.6. Protein Extraction and Western Blotting. Total proteins were prepared by dissolving in solubilizing buffer $(50 \mathrm{mM}$ Tris- $\mathrm{HCl}$ pH 8.0, $150 \mathrm{mM} \mathrm{NaCl}, 0.5 \%$ Triton X-100, 2 mM PMSF, $10 \mu \mathrm{g} / \mathrm{mL}$ protease inhibitor, $1 \mathrm{mM} \mathrm{Na}_{3} \mathrm{VO}_{4}$, and $1 \mathrm{mM} \mathrm{NaF}$ ) LAN5 cells untreated (control) or treated with oligomers, alone or with insulin. Protein samples $(20 \mu \mathrm{g})$ were electrophoretically separated using 10\% SDS-PAGE gel and transferred onto nitrocellulose filters for immunoblotting. After blocking in 3\% BSA in TBST, the Western blot was incubated with antiphosphorylated Hsp70 (Hsp70) ( 1 : 1000; Cell Signalling) or anticonstitutive Hsp70 (Hsc70) ( $1: 500$; Cell Signalling) or anti $\beta$-actin $(1: 1000)$. Primary antibodies were detected using the ECL chemiluminescence kit (Amersham) according to the manufacturer's instructions and using secondary antibodies conjugated to horseradish peroxidase (1:1500; Amersham). Band intensities were analyzed with a gel documentation system (BioRad). Hsp70 and Hsc70 expression were adjusted to $\beta$-actin expression. The protein levels were expressed as densitometry.

2.7. Statistical Analysis. All experiments were repeated at least three times. Each experiment was performed in triplicate. The results are presented as mean \pm SD. Statistical evaluation was conducted by ANOVA, followed by Student's $t$-test for analysis of significance. $P<.05$ was considered statistically significant.

\section{Results}

3.1. Insulin Protects Neuroblastoma Cells against rA $\beta 42$ Oligomers Toxicity. As a first step to evaluate the amount of insulin necessary to interfere with cell damage induced by A-beta oligomers, a dose-response study was performed. LAN5 neuroblastoma cells were treated before with different amounts of $\mathrm{rA} \beta 42$ oligomers $(25,40 \mu \mathrm{M})$ and then with different insulin concentrations $(50,100,200 \mu \mathrm{M})$.

As shown in Figure 1(a), cells treated with $\operatorname{rA} \beta 42,25 \mu \mathrm{M}$ or $40 \mu \mathrm{M}$ showed a mortality of about $60 \%$ and $85 \%$, 


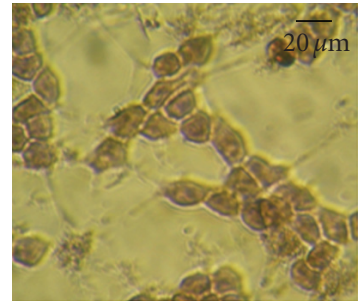

(a)

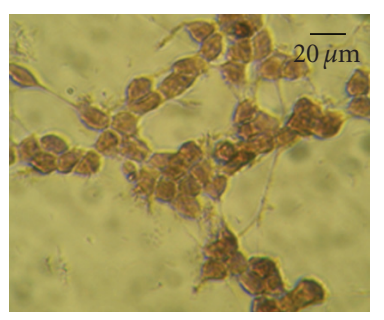

(c)

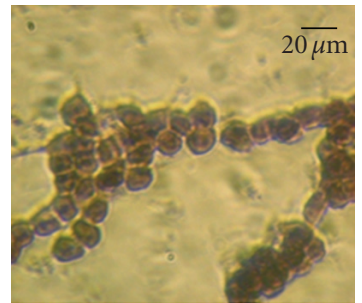

(b)

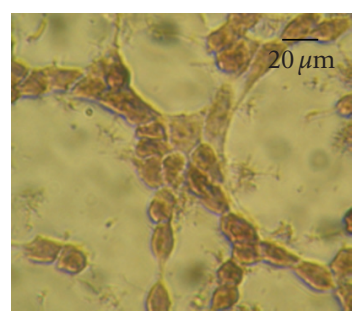

(d)
Figure 2: Protective effect of insulin against $\mathrm{rA} \beta 42$ oligomers induced apoptosis. LAN5 untreated cells as control (a), treated with $\mathrm{rA} \beta 42$ oligomers $(40 \mu \mathrm{M})$ for $1 \mathrm{~h}(\mathrm{~b})$, with $\mathrm{rA} \beta 42(40 \mu \mathrm{M})$ for $1 \mathrm{~h}$ and with insulin $(100 \mu \mathrm{M})$ for $20 \mathrm{~h}(\mathrm{c})$, insulin alone $(100 \mu \mathrm{M})$ for $20 \mathrm{~h}$ (d) were fixed and put through TUNEL assay. Bar $20 \mu \mathrm{m}$.

respectively, if compared to the control. When insulin was added, in the sample previously treated with oligomers, a recovery of cell viability of about $20 \%$ for the minor concentration and $100 \%$ for the higher concentration was observed, indicating that insulin plays a protective effect against A-beta toxicity (Figure 1(a)).

Moreover, to visualize the results obtained by the viability assay, the morphological effect compared to the corresponding controls was examined by microscopic inspection. Neurons treated with $\mathrm{rA} \beta 42$ oligomers at different degeneration steps were observed and some representative images are shown in Figure 1(b). Morphological changes resulted in a reduction of the cellular body, neuritis, and cell numbers. Cells treated with rA $\beta 42$ oligomers and insulin appeared to recover the regular morphology of neurons.

\subsection{Insulin Reduces Apoptosis Induced by rA $\beta 42$ Oligomers.} In apoptosis a biochemical cascade activates proteases that destroy biomolecules required for cell survival. During this process the cytoplasm condenses, organelles aggregate, chromatin condenses, and nucleus fragments [16]. After cell treatment with $\mathrm{rA} \beta 42$ oligomers, we detected in the survived cells morphological modifications, typical hallmarks of the apoptosis process. In particular granules, resembling apoptotic bodies, were observable (data not shown). To investigate if insulin can revert this effect, LAN5 cells were put through to the TUNEL assay after treatment with oligomers alone or with oligomers and insulin. An intense brown nuclear staining is visible in the cells treated with rA $\beta 42$ (Figure 2(b)), indicating that the apoptotic process has been triggered, whereas no staining is detectable in the cells treated with oligomers and insulin (Figure 2(c)), as seen for the control cells (Figures 2(a) and 2(d)).
3.3. Insulin Inhibits Intrinsic Apoptotic Pathway Induced by $r A \beta 42$ Oligomers. The major executioners in the apoptotic program are proteases known as caspases. In some forms of apoptosis, the extrinsic apoptotic pathway is initiated by activation of caspase 8 after death receptor binding; in other forms, activation of the intrinsic apoptotic pathway is initiated by signaling molecules, recruited by mitochondria. They lead a release of cytochrome $\mathrm{C}$ from mitochondrial matrix to cytoplasm where it binds to Apaf-1 protein to form the apoptosome that activates caspase 9 [16]. Both these pathways are able to activate the executrix caspase- 3 involved in the final part of death process. To identify in which $\mathrm{rA} \beta 42-$ oligomer induced apoptotic pathway insulin interferes, we performed caspase 8 and caspase 9 luminometric assays. A caspase activator was employed as a control. According to previous results, no activation of capsase 8 by oligomers stimulus occurred [15] and the same result for insulin stimulus was obtained (Figure 3(a)). Instead, as can be seen in Figure 3(b), A-beta oligomers activate caspase 9 and this activation is noticeably reduced by the presence of insulin, indicating, once again, that insulin is able to produce a positive protective effect. In order to confirm this result, LAN5 cells treated as described above were put through to caspase 3 assay, the typical executrix caspase. As expected, in the LAN5 cells treated with oligomers and insulin a reduction in the caspase 3 activation with respect to the A-beta oligomer treated cells was detected (Figure 3(c)). These results confirm that A-beta oligomers induce intrinsic apoptotic pathway and the insulin is able to down-regulate caspases 9 and 3 activation.

\subsection{Insulin Recovers Mitochondrial Respiratory Activity} Reduced by rAß42 Oligomers. Caspase 9 activation is considered an event subsequent to mitochondrial damage. In order to confirm that a dysfunction of this organelle occurred after A-beta stimulus and this dysfunction is replaced or avoided by insulin treatment, we tested the metabolic activity of the mitochondria by using Mito red, a specific dye that permits to measure the respiratory activity. Once the dye is introduced into the cells, it freely diffuses through the outer mitochondrial membrane and enters exclusively into the mitochondrial matrix of the metabolically active mitochondrials. The red staining, shown in Figure 4, indicates mitocondrial activity. Moreover, the nucleus integrity was visualized by staining the samples with the specific Hoechst dye. In Figure 4 an intense red staining, comparable to the control cells, was observed in cell treated with Abeta oligomers and insulin and no intense blue staining, indicating nuclear fragmentation, was observed. In contrast, absence of red staining is visible in the cells treated with A-beta oligomers alone, while an intensive blue staining is evident, stating the presence of DNA nicks, a typical apoptosis hallmark. This analysis confirms that the $\operatorname{rA} \beta 42$ induced degeneration, via mitochondrial damage, has been counteracted by insulin addition.

3.5. Modulation of Stress Response Activation. Hsp70 has a negative regulatory role in apoptosis and is activated, by phosphorylation process, in response to a variety of 


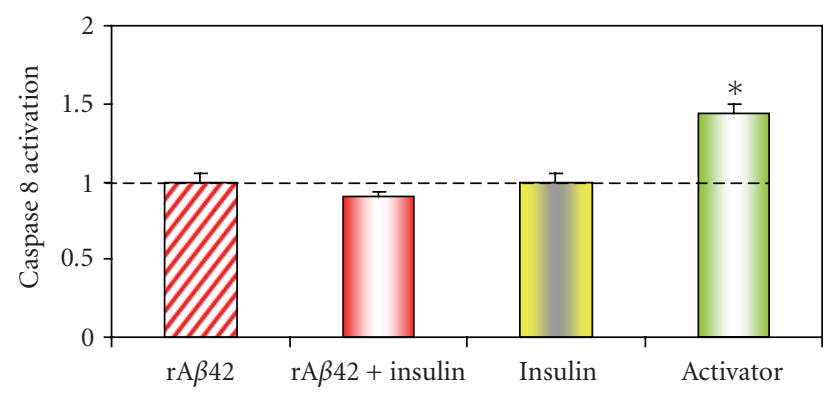

(a)

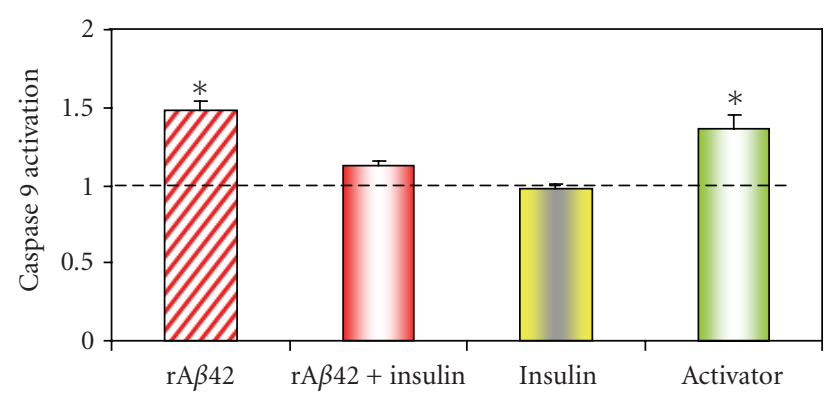

(b)

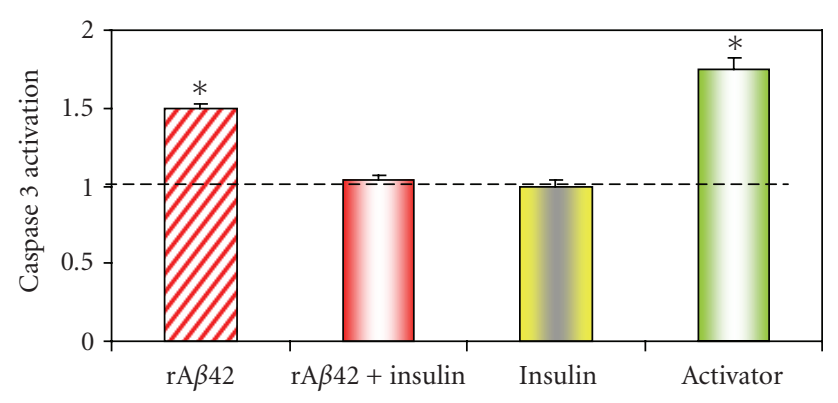

(c)

FIgURE 3: Effects of insulin against rA $\beta 42$ oligomers on caspase 9 and 3 activation. LAN5 were untreated (control), treated with $\mathrm{rA} \beta 42$ oligomers $(40 \mu \mathrm{M})$ for $1 \mathrm{~h}(\mathrm{rA} \beta 42), \mathrm{rA} \beta 42$ oligomers $(40 \mu \mathrm{M})$ for $1 \mathrm{~h}$ and insulin $(100 \mu \mathrm{M})$ for $4 \mathrm{~h}(\mathrm{rA} \beta 42+$ insulin), insulin alone $(100 \mu \mathrm{M})$ for $4 \mathrm{~h}$ (insulin), $50 \mu \mathrm{M}$ Vinblastine for $4 \mathrm{~h}$ (activator) and submitted to caspase 8 (a), caspase 9 (b), and caspase 3 (c) luminescent assays. Data expressed as percentage of the corresponding control. The dashed line shown in the histogram corresponds to a control culture. The activation of caspase 8 (a) is significantly high with activator ${ }^{*} P<.02$, whereas it is not significantly high in $\mathrm{rA} \beta 42$ versus control. The activation of caspase 9 (b) is significantly high in $\operatorname{rA} \beta 42{ }^{*} P<.01$ and in the activator ${ }^{*} P<.05$, whereas it is not significantly high in $\mathrm{rA} \beta 42+$ insulin versus control. The activation of caspase 3 (c) is significantly high in $\mathrm{rA} \beta 42{ }^{*} P<.01$ and in the activator ${ }^{*} P<.01$, whereas it is not significantly high in $\mathrm{rA} \beta 42+$ insulin versus control. Values are referred to control, the data are the mean \pm SD of three separate experiments.
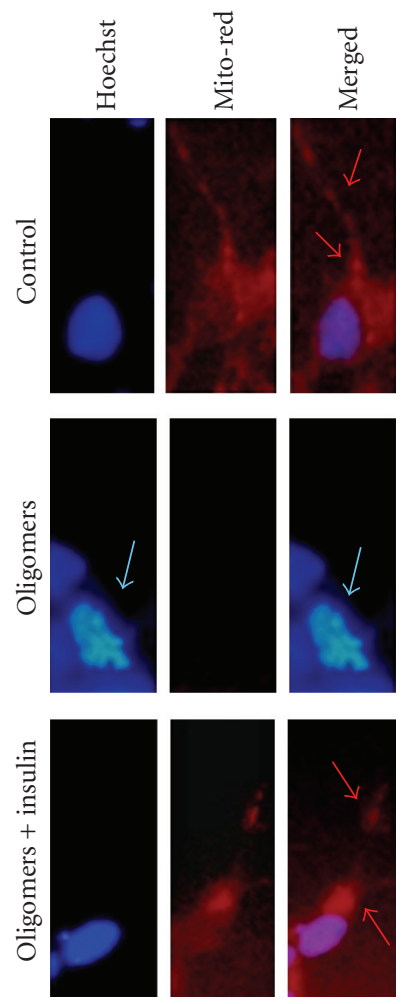

FIgURE 4: Insulin recovers mitochondrial respiratory activity, reduced by $\mathrm{rA} \beta 42$ oligomers. LAN5 were untreated (control), treated with $\mathrm{rA} \beta 42$ oligomers $(40 \mu \mathrm{M})$ for $1 \mathrm{~h}$ (oligomers), $\mathrm{rA} \beta 42$ oligomers $(40 \mu \mathrm{M})$ for $1 \mathrm{~h}$ and insulin $(100 \mu \mathrm{M})$ for $20 \mathrm{~h}$ (oligomers + insulin). Cells were incubated with Mito Red and Hoechst 33258. The images of each sample were merged. Red staining indicates mitochondrial activity (see red arrows). Blue staining indicates nuclear fragmentation (see blue arrows).

stress stimuli. To test whether the insulin can play its protective role by activating or improving activation of Hsp70, a Western blot experiment was performed. Same amounts of proteins extracted from cells, (i) untreated, (ii) A-betatreated, (iii) treated with insulin alone, and (iv) previously treated with A-beta, were loaded on a SDSPAGE. The immunoblot was incubated with antibodies against both the constitutive and inducible Hsp70 stress proteins and antißactin for normalizing gel loading. Levels of the constitutively expressed Hsp70 form (Hsc70) do not change after any stimulus. In agreement with other studies [17], A-beta presence increased the Hsp70 stress-inducible form (Hsp70) as compared with the control (Figure 5). In contrast no activation was detected when LAN5 cells were incubated with insulin alone. Moreover, insulin enhanced Abeta mediated activation of Hsp70 suggesting that this major induction could be necessary to complete a cell survival program.

\section{Discussion}

An increasing number of reports suggest that A-beta accumulates inside neurons with aging and that A-beta 


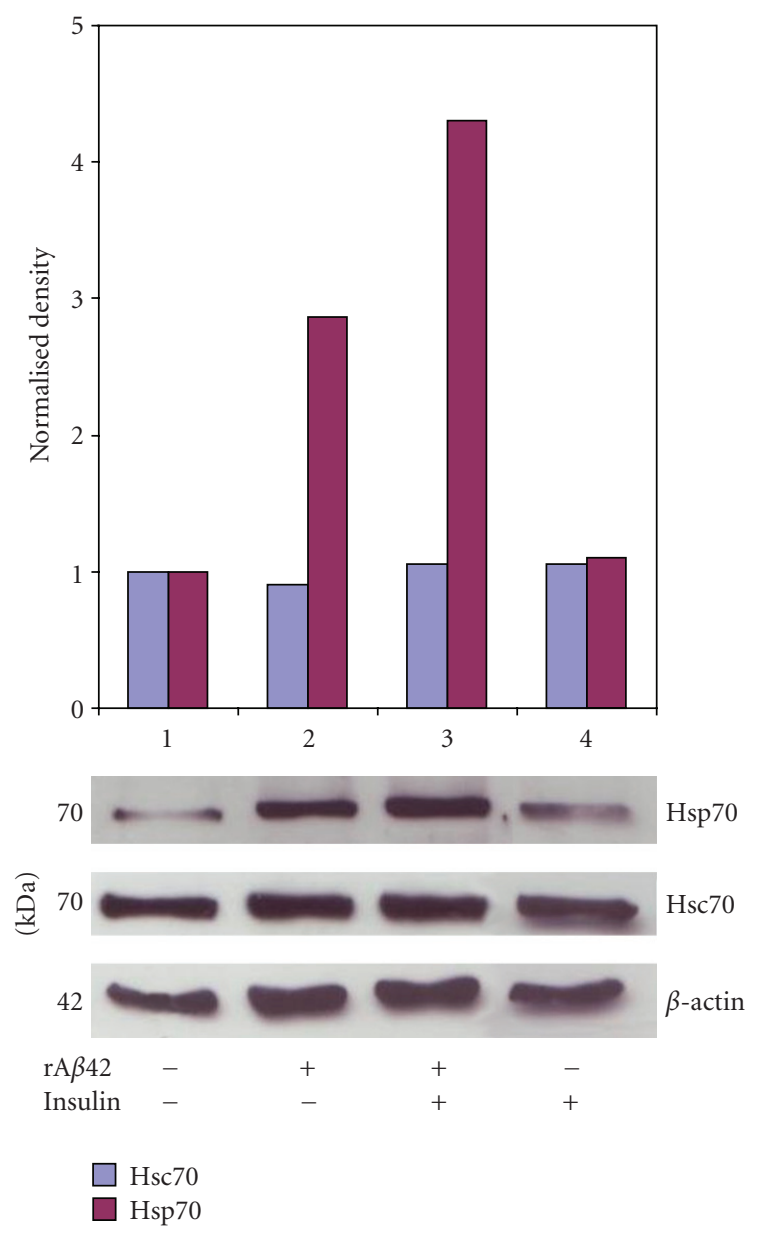

FIGURE 5: Insulin enhances inducible Hsp70 activation triggered by rA $\beta 42$ oligomers. Western blot of proteins extracted from LAN5 untreated (1), treated with $\mathrm{rA} \beta 42$ oligomers $(40 \mu \mathrm{M})$ for $1 \mathrm{~h}(2)$, $\mathrm{rA} \beta 42$ oligomers $(40 \mu \mathrm{M})$ for $1 \mathrm{~h}$ and insulin $(100 \mu \mathrm{M})$ for $20 \mathrm{~h}(3)$, insulin alone $(100 \mu \mathrm{M})$ for $20 \mathrm{~h}(4)$, incubated with anticonstitutive Hsp70 (Hsc70), antiinducible Hsp70 (Hsp70) or beta-actin ( $\beta$ actin). Uniformity of gel loading was confirmed with $\beta$-actin as standard. Quantification of immunoreactivity was performed using densitometric analysis.

aggregation can be an initial event for the characteristic cell degeneration present in the Alzheimer's pathology. A-beta aggregated molecules alter normal cell homeostasis including impaired glucose/energy metabolism, mitochondrial dysfunction and oxidative stress [18]. Recently, several studies suggest that disturbance in insulin metabolism, especially insulin resistance, plays a role in the onset and development of $\mathrm{AD}$. Thus, growing evidence begins to find links between $\mathrm{AD}$ and type 2 diabetes and, for this reason, $\mathrm{AD}$ has been considered the "brain-type diabetes" [5, 19]. Here we provide evidence that insulin can protect cells against damage induced by A-beta oligomers avoiding the apoptosis program.

We found that insulin inhibits A-beta cell death in LAN5 neuroblastoma cells in a dose-dependent manner. According to several results different are the hypothesis reported to explain a mechanism underlying the protective role played by insulin to contrast the impairment produced by A-beta oligomers. Among the first studies, it has been demonstrated that specifically dibutyryl cAMP or insulin inhibit toxic effect of A-beta $22-35$ in cultured rat hippocampal neurons and a recover of the intracellular signal transduction disorder was suggested [11]. More recently, on the basis that A-beta and insulin are both amyloidogenic peptides sharing a common sequence recognition motif [20], it has been reported that Abeta hinders the insulin binding to its receptor (IR), leading to an IR reduced autophosphorylation [12]. The authors suggest that the link between A-beta and insulin is associated to the impairment of glucose utilization, and in agreement to this hypothesis, a recovery of cell viability, through insulin administration could be due to the retrieval of normal glucose metabolism. Other authors [10] suggest that insulin inhibits A-beta fibril network formation, an essential step in exerting its toxicity, at the cell surface of human brain pericytes (HBP). In fact, the HBP line does not express IR, therefore in this case the protective effect of insulin can not be due to its reduced binding to IR. All the results reported above underline that insulin is able to recover an intracellular damage induced by A-beta, whose effect is to produce cellular stress and degeneration. Apoptosis has been often associated to neurodegeneration [21] and to find a mechanism that control caspase activation could be a promising approach to hinder the cell death process. By specific assays, we demonstrate that insulin opposes to apoptotis and particularly caspase 9 and 3 activation after A-beta induced toxicity. According to previous results caspase 8 was not activated by A-beta oligomers, because the extrinsic pathway is a preferential process activated by larger A-beta fibrils [15]. Caspase 9 activation is a consequence of mitochondrial dysfunction often provoked by oxidative stress, and increased oxidative stress has been implicated in the etiology of several pathology including diabetes and $\mathrm{AD}[22,23]$. Mitochondria are both the major generators and direct targets of reactive oxygen species (ROS) and this had led to the idea that oxidative stress and mitochondrial damage are contributory factors to several disorders. Moreover, it has been demonstrated that, in the presence of Abeta, insulin prevents the decline in mitochondrial oxidative phosphorylation efficiency and avoids an increase in oxidative stress [24]. These data are in agreement with the result here shown that the mitochondrial activity is impaired when the neuroblastoma cells are treated with A-beta oligomers and that this effect is recovered when insulin is added. Moreover, insulin prevents apoptotic pathway activation as observable by the absence of nuclear fragmentation, that instead is well evident in the oligomers treated cells. Thus, we suggest that insulin prevents mitochondrial dysfunction probably by inhibition of ROS formation and activating specific cell signaling (work in progress). Further, it is known that insulin activates the serine-threonine kinase Akt, a protein downstream of PI3K, involved in survival pathway [25-27]. Akt has been well demonstrated to phosphorylating and increasing the expression of a number of proteins involved in apoptotic signaling cascade such as the Bcl2 family [28, 29]. Presence of A-beta produces a toxic effect, responsible for the observed neuron death. Some 
evidences point out the role of molecular chaperones in neurodegenerative processes $[30,31]$. We show that a stress response is activated by the increased expression of inducible Hsp70. Interestingly, A-beta is able to activate Hsp70 but, in the present experimental conditions, the endogenous stress response is insufficient to revert the apoptotic pathway. Upregulation of Hsp70 has been found in neurons treated with A-beta and a modulator role in A-beta toxicity has been proposed [17]. The authors hypothesize that an imbalance between the neuronal Hsp protective capacity and the toxic accumulation of A-beta could be the cause of the neuronal death. The presence of insulin enhances the activation of the stress proteins, suggesting that an increased survival program has been activated and the neurons recover their viability. Moreover, it has been demonstrated that Hsp70 is induced by PI3/Akt activation [32] that in turn is activated by insulin. Heat shock proteins can neutralize the neurotoxicity in animal models suggesting potential therapeutic approaches in neurodegeneration associated with abnormal folding and toxicity $[33,34]$. Other observations have demonstrated the presence of Hsp70 in AD brain [35]. Hsp70 plays a role in preventing protein aggregation and degradation [36, 37]. Helped by insulin, that increases its expression and activation, we can assume that Hsp70 could prevent Abeta oligomers by successive aggregation steps or promote oligomers degradation.

\section{Conclusions}

The present data point out the protective action of insulin in inhibiting A-beta cell toxicity and they could be an initial step to understand as insulin resistance or disturbance in insulin metabolism can contribute to neurodegeneration. Moreover, insulin may constitute a therapeutic agent against $\mathrm{AD}$, activating cell survival signaling pathways.

\section{Acknowledgment}

M. Di. Carlo and P. Picone contributed equally to this work.

\section{References}

[1] T. Wisniewski, J. Ghiso, and B. Frangione, "Biology of A $\beta$ amyloid in Alzheimer's disease," Neurobiology of Disease, vol. 4, no. 5, pp. 313-328, 1997.

[2] F. Chiti and C. M. Dobson, "Protein misfolding, functional amyloid, and human disease," Annual Review of Biochemistry, vol. 75, pp. 333-366, 2006.

[3] M. Di Carlo, "Beta amyloid peptide: from different aggregation forms to the activation of different biochemical pathways," European Biophysics Journal, vol. 39, pp. 877-888, 2010.

[4] A. E. Shrimpton, R. L. Schelper, R. P. Linke, et al., "A presenilin 1 mutation (L420R) in a family with early onset Alzheimer disease, seizures and cotton wool plaques, but not spastic paraparesis," Neuropathology, vol. 27, no. 3, pp. 228-232, 2007.

[5] P. I. Moreira, A. I. Duarte, M. S. Santos, A. C. Rego, and C. R. Oliveira, "An integrative view of the role of oxidative stress, mitochondria and insulin in Alzheimer's disease," Journal of Alzheimer's Disease, vol. 16, no. 4, pp. 741-761, 2009.
[6] Z. Arvanitakis, R. S. Wilson, J. L. Bienias, D. A. Evans, and D. A. Bennett, "Diabetes mellitus and risk of Alzheimer disease and decline in cognitive function," Archives of Neurology, vol. 61, no. 5, pp. 661-666, 2004.

[7] K. F. Neumann, L. Rojo, L. P. Navarrete, G. Farías, P. Reyes, and R. B. Maccioni, "Insulin resistance and Alzheimer's disease: molecular links \& clinical implications," Current Alzheimer Research, vol. 5, no. 5, pp. 438-447, 2008.

[8] J. S. Roriz-Filho, T. M. Sá-Roriz, I. Rosset, et al., "(Pre)diabetes, brain aging, and cognition," Biochimica et Biophysica Acta, vol. 1792, no. 5, pp. 432-443, 2009.

[9] M. E. Tucker, "Diabetes drug appears to slow cognitive decline," Clinical Psychiatry News, vol. 33, no. 2, p. 42, 2005.

[10] A. A. M. Rensink, I. Otte-Höller, R. De Boer, et al., "Insulin inhibits amyloid $\beta$-induced cell death in cultured human brain pericytes," Neurobiology of Aging, vol. 25, no. 1, pp. 93-103, 2004.

[11] T. Takadera, N. Sakura, T. Mohri, and T. Hashimoto, "Toxic effect of a $\beta$-amyloid peptide ( $\beta 22-35)$ on the hippocampal neuron and its prevention," Neuroscience Letters, vol. 161, no. 1, pp. 41-44, 1993.

[12] L. Xie, E. Helmerhorst, K. Taddei, B. Plewright, W. Van Bronswijk, and R. Martins, "Alzheimer's beta-amyloid peptides compete for insulin binding to the insulin receptor," The Journal of Neuroscience, vol. 22, no. 10, article RC221, 2002.

[13] W.-Q. Zhao, F. G. De Felice, S. Fernandez, et al., "Amyloid beta oligomers induce impairment of neuronal insulin receptors," FASEB Journal, vol. 22, no. 1, pp. 246-260, 2008.

[14] R. Carrotta, M. Di Carlo, M. Manno, et al., "Toxicity of recombinant $\beta$-amyloid prefibrillar oligomers on the morphogenesis of the sea urchin Paracentrotus lividus," FASEB Journal, vol. 20, no. 11, pp. E1301-E1308, 2006.

[15] P. Picone, R. Carrotta, G. Montana, M. R. Nobile, P. L. San Biagio, and M. Di Carlo, "A $\beta$ oligomers and fibrillar aggregates induce different apoptotic pathways in LAN5 neuroblastoma cell cultures," Biophysical Journal, vol. 96, no. 10, pp. 42004211, 2009.

[16] J. F. Kerr, A. H. Wyllie, and A. R. Currie, "Apoptosis: a basic biological phenomenon with wide-ranging implications in tissue kinetics," British Journal of Cancer, vol. 26, no. 4, pp. 239-257, 1972.

[17] J. Magrané, R. C. Smith, K. Walsh, and H. W. Querfurth, "Heat shock protein 70 participates in the neuroprotective response to intracellularly expressed $\beta$-amyloid in neurons," Journal of Neuroscience, vol. 24, no. 7, pp. 1700-1706, 2004.

[18] H. W. Querfurth and F. M. La Ferla, "Alzheimer's disease," The New England Journal Medicine, vol. 362, no. 4, pp. 329-344, 2010.

[19] Z. Kroner, “The relationship between Alzheimer's disease and diabetes: type 3 diabetes?" Alternative Medicine Review, vol. 14, no. 4, pp. 373-379, 2009.

[20] M. M. Pallitto, J. Ghanta, P. Heinzelman, L. L. Kiessling, and R. M. Murphy, "Recognition sequence design for peptidyl modulators of $\beta$-amyloid aggregation and toxicity," Biochemistry, vol. 38, no. 12, pp. 3570-3578, 1999.

[21] R. M. Friedlander, "Apoptosis and caspases in neurodegenerative diseases," The New England Journal of Medicine, vol. 348, no. 14, pp. 1365-1375, 2003.

[22] A. Eckert, U. Keil, C. A. Marques, et al., "Mitochondrial dysfunction, apoptotic cell death, and Alzheimer's disease," Biochemical Pharmacology, vol. 66, no. 8, pp. 1627-1634, 2003.

[23] M. A. Yorek, "The role of oxidative stress in diabetic vascular and neural disease," Free Radical Research, vol. 37, no. 5, pp. 471-480, 2003. 
[24] P. I. Moreira, M. S. Santos, C. Sena, R. Seiça, and C. R. Oliveira, "Insulin protects against amyloid $\beta$-peptide toxicity in brain mitochondria of diabetic rats," Neurobiology of Disease, vol. 18, no. 3, pp. 628-637, 2005.

[25] C. A. Bondy and C. M. Cheng, "Signaling by insulin-like growth factor 1 in brain," European Journal of Pharmacology, vol. 490, no. 1-3, pp. 25-31, 2004.

[26] G. Song, G. Ouyang, and S. Bao, "The activation of Akt/PKB signaling pathway and cell survival," Journal of Cellular and Molecular Medicine, vol. 9, no. 1, pp. 59-71, 2005.

[27] H.-K. Lee, P. Kumar, Q. Fu, K. M. Rosen, and H. W. Querfurth, "The insulin/Akt signaling pathway is targeted by intracellular $\beta$-amyloid," Molecular Biology of the Cell, vol. 20, no. 5, pp. 1533-1544, 2009.

[28] A. I. Duarte, P. Santos, C. R. Oliveira, M. S. Santos, and A. C. Rego, "Insulin neuroprotection against oxidative stress is mediated by Akt and GSK-3beta signalling pathways and changes in protein expression," Biochimica et Biophysica Acta, vol. 1783, no. 6, pp. 994-1002, 2008.

[29] S. R. Datta, H. Dudek, T. Xu, et al., "Akt phosphorylation of BAD couples survival signals to the cell- intrinsic death machinery," Cell, vol. 91, no. 2, pp. 231-241, 1997.

[30] N. M. Bonini, "Chaperoning brain degeneration," Proceedings of the National Academy of Sciences of the United States of America, vol. 99, supplement 4, pp. 16407-16411, 2002.

[31] H. Sakahira, P. Breuer, M. K. Hayer-Hartl, and F. U. Hartl, "Molecular chaperones as modulators of polyglutamine protein aggregation and toxicity," Proceedings of the National Academy of Sciences of the United States of America, vol. 99, supplement 4, pp. 16412-16418, 2002.

[32] M. Bogatch, N. R. Kreisman, and B. S. Beckman, "The heat shock protein 70 (Hsp70)/PI3-K/Akt/HIF/biologic pathway as a putative determinant of hypothermic preconditioning in neuroprotection," Bioscience Hypotheses, vol. 1, no. 4, pp. 203 208, 2008.

[33] J. M. Warrick, H. Y. E. Chan, G. L. Gray-Board, Y. Chai, H. L. Paulson, and N. M. Bonini, "Suppression of polyglutaminemediated neurodegeneration in Drosophila by the molecular chaperone HSP70," Nature Genetics, vol. 23, no. 4, pp. 425428, 1999.

[34] C. J. Cummings, Y. Sun, P. Opal, et al., "Over-expression of inducible HSP70 chaperone suppresses neuropathology and improves motor function in SCA1 mice," Human Molecular Genetics, vol. 10, no. 14, pp. 1511-1518, 2001.

[35] J. E. Hamos, B. Oblas, D. Pulaski-Salo, W. J. Welch, D. G. Bole, and D. A. Drachman, "Expression of heat shock proteins in Alzheimer's disease," Neurology, vol. 41, no. 3, pp. 345-350, 1991.

[36] P. J. Muchowski, G. Schaffar, A. Sittler, E. E. Wanker, M. K. Hayer-Hartl, and F. U. Hartl, "Hsp70 and Hsp40 chaperones can inhibit self-assembly of polyglutamine proteins into amyloid-like fibrils," Proceedings of the National Academy of Sciences of the United States of America, vol. 97, no. 14, pp. 7841-7846, 2000.

[37] J. L. Dul, D. P. Davis, E. K. Williamson, F. J. Stevens, and Y. Argon, "Hsp70 and antifibrillogenic peptides promote degradation and inhibit intracellular aggregation of amyloidogenic light chains," Journal of Cell Biology, vol. 152, no. 4, pp. 705$715,2001$. 

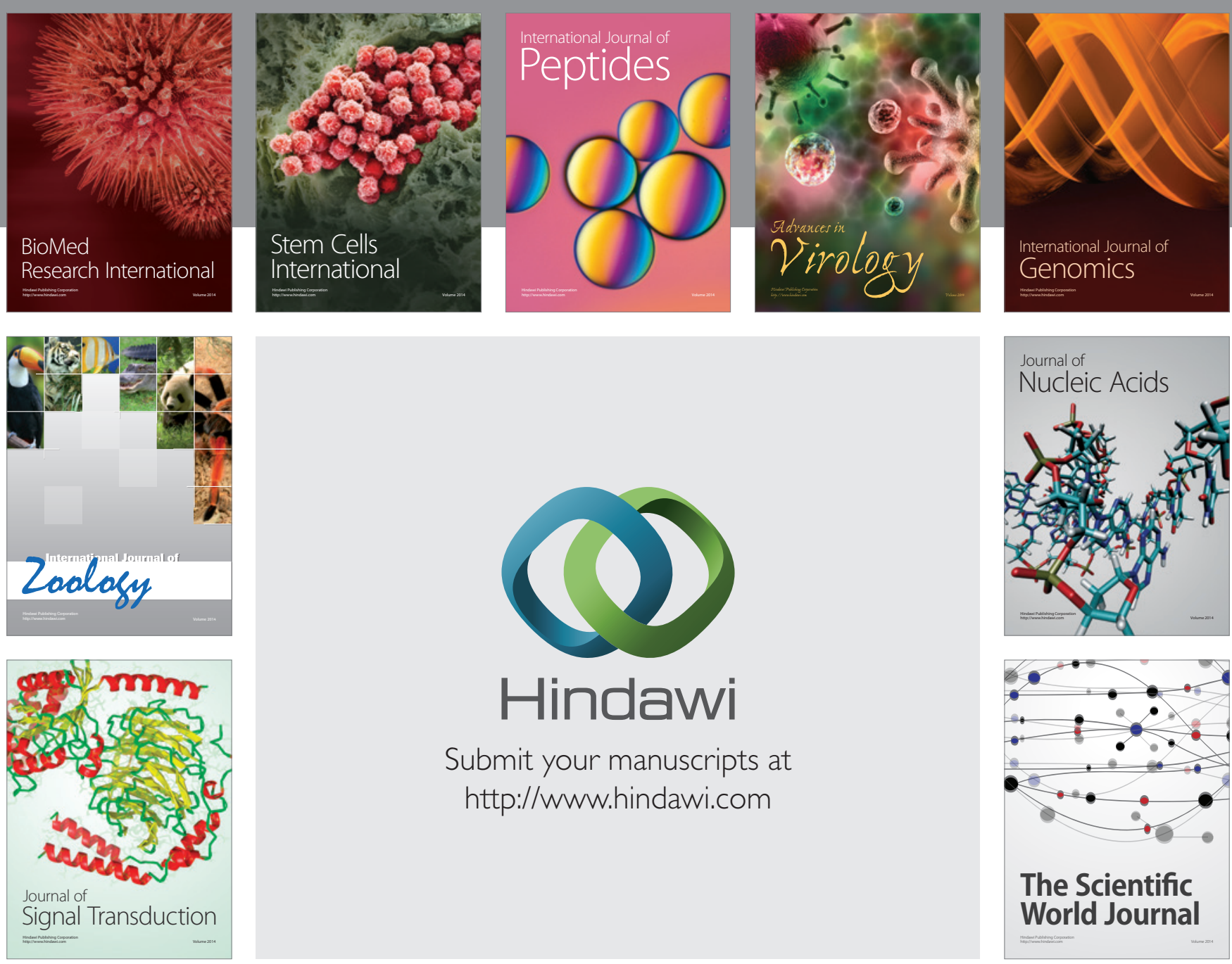

Submit your manuscripts at

http://www.hindawi.com
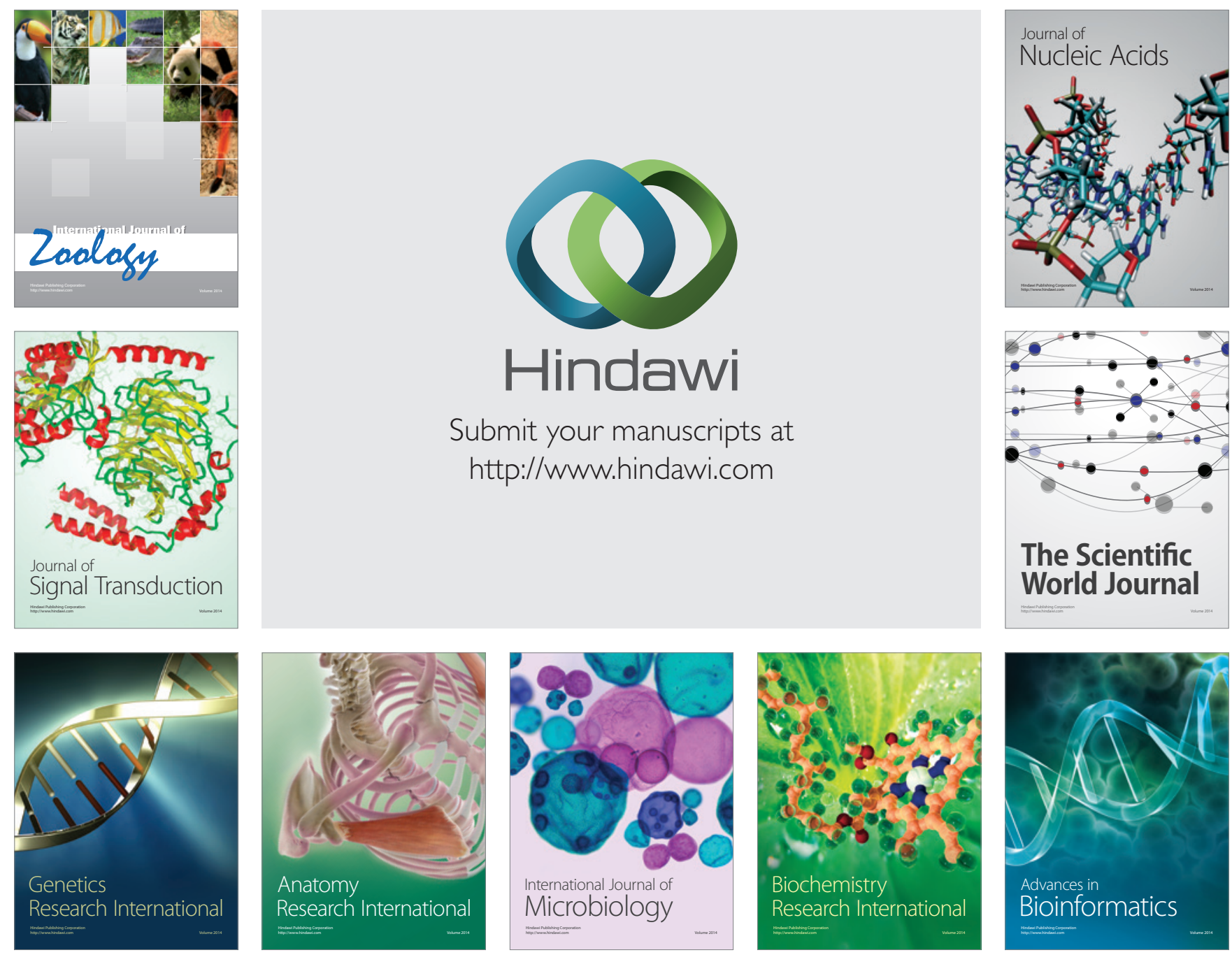

The Scientific World Journal
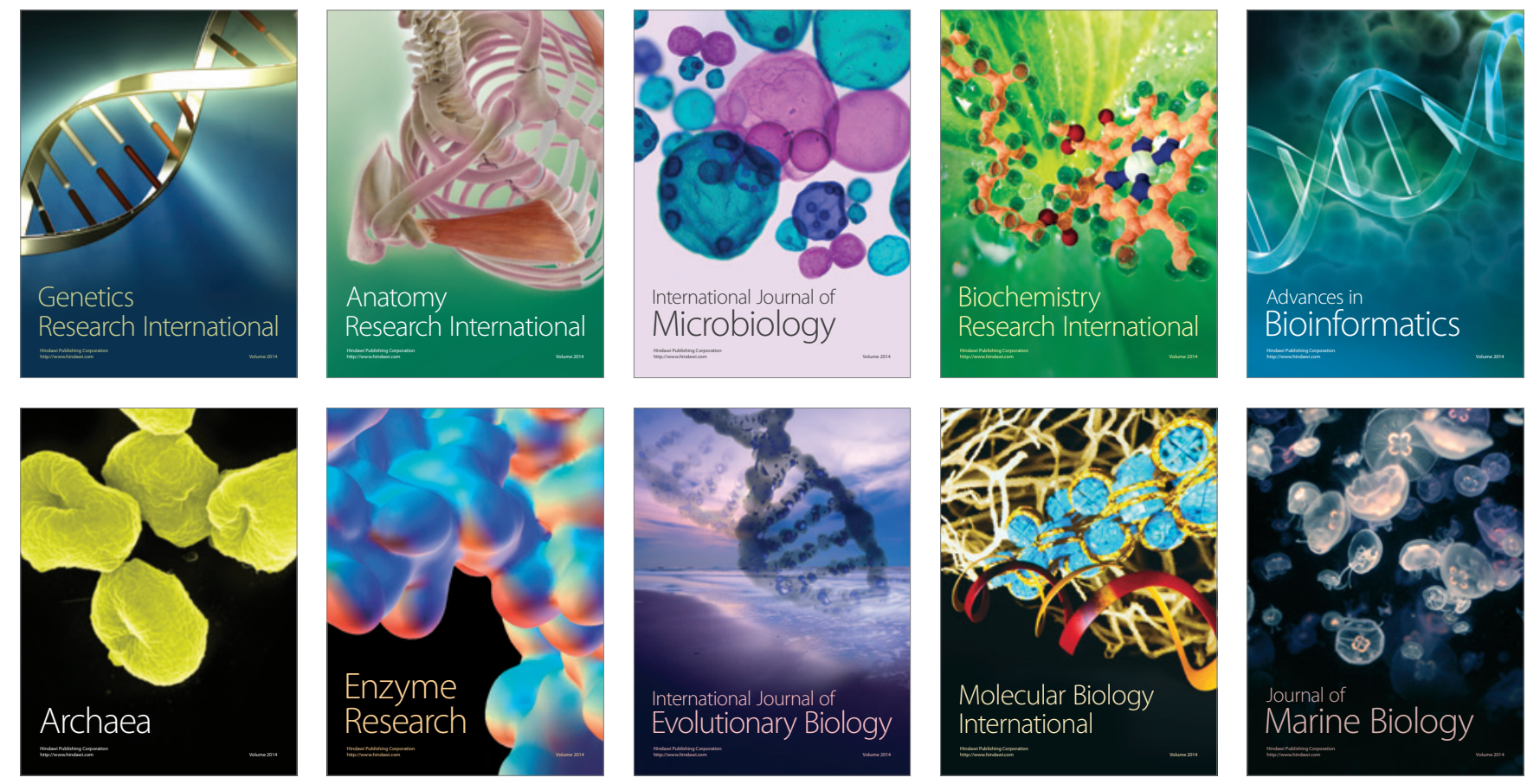